UDC 519.86

DOI: $10.20535 /$ SRIT.2308-8893.2021.3.08

\title{
TECHNOLOGY PROGRESS IMPLEMENTATION BASED ON A MODIFIED VERSION OF R.M. SOLOW ECONOMIC GROWTH MODEL: WITH PRODUCTION S-CURVE CONSISTING OF $n$-STEPS
}

\begin{abstract}
A.K. LOPATIN
Abstract. The comparative analysis of the neoclassical Solow's model and the modified Solow's model in the implementation of technological progress has shown undeniable advantages of the modified Solow's model. A modified version of the Solow's economic growth model, based on an $n$-step production function in the form of $n S$-shaped functions for the implementation of technological progress, ensures the growth of the economy on a sufficiently large time interval comparable to the duration of the life cycle of the economy under study. In this interval, referred to as the "technology gap", intensive output $y(t)$ can be carried out according to the following options: monotonic decrease (stable 1-cycle) of the considered model; oscillations (stable $n$-cycles, $n=, 2,4,16, \ldots$ ), "the economy marks time"; chaotic fluctuations. This result for the models of economic growth has not been described in the literature.
\end{abstract}

Keywords: modified Solow's model, technology gap, periodic cycles and chaos.

\section{INTRODUCTION}

In this work, we have obtained a further development of a modified version of the Solow economic growth model, based on an $n$-step production function in the form of $n S$-shaped functions for the implementation of technical progress, proposed in [1]. The substantiation of the dependence of macroeconomic dynamics on technological investment priorities in the form of $S$-shaped production functions has been considered in numerous works (see the review article [2] and the monograph [3]. In this work, we follow [4] and [5] The development process of each technological paradigm, in general, is described by a logistic curve, which expresses the most general laws of the dynamics of progressive cyclic processes. At the beginning of the life cycle of each technological paradigm, significant costs for its development give insignificant results - the first flat section of the logistic curve corresponds to this period. Then, with the development and practical mastering of the corresponding technical and technological principles, small costs begin to bring a significant effect and the curve rises steeply. Further, as the technologies of this paradigm are approaching their technological limits, this technological paradigm again enters a gentle section of the curve, and no, even large-scale investments in its development are no longer able to bring a significant effect. At the disposal of the investor at any given time, there is a limited number of technologies that could potentially be supported by his investment resources. The meaning of overcoming the period of technological gap, which is repeated from time to time in each 
branch of the economy, is to quickly and as little loss as possible change from one logistic curve to another, corresponding to a more progressive technological order. In this case, the correct choice of a substitute technology entirely depends on the correctness of estimates of the upper technological limits of several competing technologies designed to solve the same technical problem. There is a need for a transition to a new technological paradigm. This is one of the most difficult problems of technical and economic forecasting. A modified version of the Solow's economic growth model, based on an $n$-step production function in the form of $n S$-shaped functions for the implementation of technological progress, proposed in [1], gives an adequate mathematical apparatus for solving this problem. This work develops the results of work [1] in the following directions:

- comparative analysis of neoclassical Solow's model and the modified Solow's model in the implementation of techno- logical progress;

- development of a constructive algorithm based on the apparatus of nonlinear discrete dynamical systems;

- development a modified model, generating periodic and chaotic cycles.

\section{Solow's model}

The founder of modern growth theory was R.M. Solow ( [6], Nobel Prize Winner in Economics 1987). Until now, due to its combination of simplicity and richness, the Solow's model is considered as the basic model of economic growth in most economics textbooks. For modern post-Solow growth theories see the overview article [7].

\section{Solow's model description}

Here we follow [8]

Assumptions:

- closed economy, producing one good using both labor and capital;

- technological progress is given and the saving rate is exogenously determined;

- no government and fixed number of firms in the economy, each with the same production technology;

- output price is constant and factor prices (including wages) adjust to ensure full utilization of all available inputs.

Neoclassical production function:

Four variables considered:

- flow of output, $Y$;

- stock of capital, $K$;

- number of workers, $L$;

- effective labor, $L A$.

Aggregate production function given by,

$$
Y=F(K, A L) .
$$

$A$ and $L$ enter multiplicatively, where $A L$ is effective labor, and technological progress enters as labor augmenting or Harrod neutral. 
Assumed characteristics of the model:

$$
\frac{\partial F}{\partial K}>0, \frac{\partial F}{\partial A L}>0, \frac{\partial^{2} F}{\partial K^{2}}>0, \frac{\partial^{2} F}{\partial(A L)^{2}}>0 .
$$

Constant returns to scale (CRS) in capital and effective labor:

$$
F(\lambda K, \lambda A L)=\lambda F(K, A L) .
$$

Intensive-form production function: output per unit of effective labor, $y$, and capital per unit of effective labor, $k$, are related by setting $\lambda=\frac{1}{A L}$ in (2),

$$
F\left(\frac{K}{A L}, 1\right)=\frac{1}{A L} F(K, A L) .
$$

Let $k=\frac{K}{A L}, y=\frac{Y}{A L}$ and $f(k)=F(k, 1)$. Equation (1) is then written as intensive-form production function

$$
y=f(k), f(0)=0 .
$$

\section{A MODIFIED VERSION OF SOLOW'S ECONOMIC GROWTH MODEL WITH n-STAGE $S$-LIKE PRODUCTION FUNCTION}

The idea of using $S$-curves in the Solow's equation was first (as it seems to us) expressed in [9] using the example of Richards $S$-curves. The main result of this work as applied to the continuous Solow equation is reduced to the classification of trajectories, similarly to what has been done in the Solow's equation in [1].

\section{A modified Solow's model description}

Let there be some $S$-curve depending on the $p+2$ parameters, and the $m$ parameter is responsible for the shift along the abscissa axis, the $u$ parameter along the ordinate axis:

$$
S_{p f}\left(v_{1}, \ldots, v_{p}, m, u\right) .
$$

Ecxample. Verholst's $S$-curve

$$
S_{p f}\left(k_{t}\right)=\frac{A}{1+B \exp \left(-a\left(k_{t}-m\right)\right)}+u
$$

here $k_{t}=\frac{K_{t}}{L_{t}}, A=5, B=0,5, a=1, m=4, u=0$.

The new production function, which will be called the $n$-stage production function $(n=1)$, is given by formula:

$$
Y=L S_{p f}\left(\frac{K}{L}\right)
$$

Let $k=\frac{K}{L}, y=\frac{Y}{L}$ and $f(k)=S_{p f}(k)$. Equation (4) is then written as intensive-form production function

$$
y=f(k) .
$$


It is assumed that the growth of working in economy is described by formula:

$$
L_{t+1}(t)=(1+n) L_{t} .
$$

Economic growth determined by the behavior of the capital stock $K$ :

$$
K_{t+1}=s^{*} L_{t} S_{p f}\left(\frac{K_{t}}{L_{t}}\right)+(1-d) K_{t} .
$$

Dividing both sides of equation (5) by $L_{t}$, after simple transformations we obtain the second $s$ to eliminate

$$
k_{t+1}=\frac{s}{1+n} s f\left(k_{t}\right)+\frac{1-d}{1+n} k_{t} .
$$

It is non-linear, first-order difference equation. Here $d=0,2$-depreciation rate, $s=0,3$-a fixed fraction of output, $0<s<1, t=0,1, \ldots, N$.

The equation (6) will be called the modified Solow's model with 1-stage production function. The model with $\mathrm{N}$ stages production function was considered in [1] and with 2 stages production function is considered in section 4 of this article.

\section{A modified Solow's model characteristics}

- All clauses of Assumption in subsection 2.1 are accepted.

- The production function can be both increasing and decreasing Growing production function (see Fig. 1 and 2).

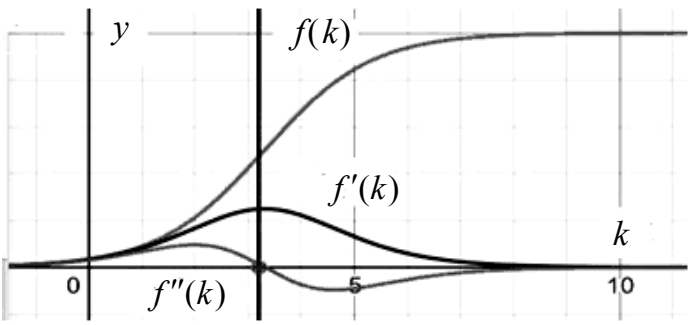

Fig. 1. Increasing production function $f(k)$

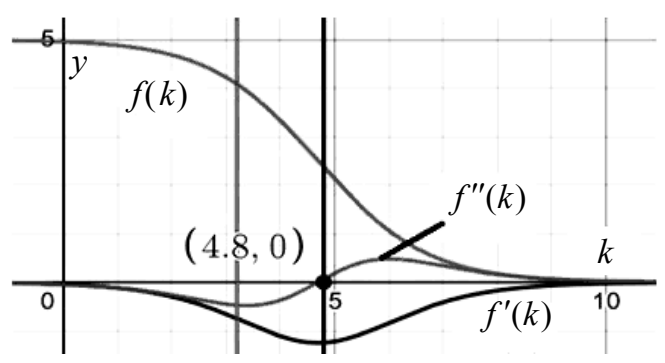

Fig. 2. Decreasing production function $f(k)$

- From three cases of equilibrium for phase trajectory we choose Case 1: Developed world (good equilibrium). The phase curve is located above the bisector and has one intersection point with it (a stable equilibrium position) [1].

- Production function (3) has more parameters than neoclassical production function.

- When changing the parameters $\mathrm{m}$ and $\mathrm{u}$, the production function can be shifted to any point in the first quarter. The condition $f(0)=0$ is not met.

- The need to use the theory of nonlinear dynamical systems to study the quantitative and qualitative characteristics of solutions to the modified Solow model. For the neoclassical model, this device has not been used in full before. 
- The $S$-shaped production function describes the life cycle of each technology: origin, leapfrogging, and gradual achievement of the stage of full maturity of a technological process or product. For the $S$-curve to be of practical value, it must predict impending technological change:

$$
\begin{aligned}
& \begin{cases}f^{\prime}(k)>0, f^{\prime \prime}(k)>0, & \text { if } x \geq \text { inflectionpoint, } \\
f^{\prime}(k)>0, f^{\prime \prime}(k)<0, & \text { if } x<\text { inflectionpoint. }\end{cases} \\
& \begin{cases}f^{\prime}(k)>0, f^{\prime \prime}(k)>0, & \text { if } x \geq \text { inflectionpoint, } \\
f^{\prime}(k)>0, f^{\prime \prime}(k)<0, & \text { if } x<\text { inflectionpoint. }\end{cases}
\end{aligned}
$$

\section{A MODIFIED MODEL, GENERATING PERIODIC AND CHAOTIC CYCLES}

\section{A modified model construction algorithm}

Consider two production functions shown in Fig. 3.

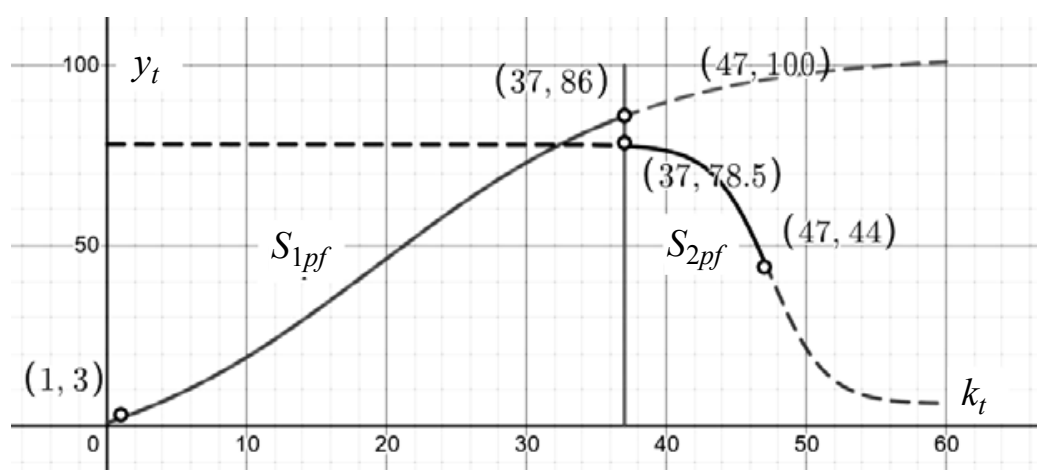

Fig. 3. Intensive production functions $S_{1 p f}$ and $S_{2 p f}$

Here

$$
\begin{gathered}
S_{1 p f}\left(k_{t}\right)=\frac{A}{1+B_{1} \operatorname{xp}\left(-a\left(k_{t}-m\right)\right)}+u, 0 \leq k_{t}<37 ; \\
\left.S_{2 p f}\left(k_{t}\right)=\frac{A_{5}}{1+B_{5} \exp \left(-a_{5}\left(k_{t}-m_{5}\right)\right)}+u_{5}, 37 \leq k_{t}<47\right\}
\end{gathered}
$$

in equations (7), (8) the parameters have the following values.

Summary of parameters used

\begin{tabular}{|c|c|c|c|c|c|c|c|c|c|}
\hline$A$ & $B$ & $a$ & $m$ & $u$ & $A_{5}$ & $B_{5}$ & $a_{5}$ & $m_{5}$ & $u_{5}$ \\
\hline 117 & 6,9 & 0,1 & 0 & $-14,1$ & 72 & 10 & $-0,5$ & 52 & 10 \\
\hline
\end{tabular}

The technique for finding the variables $k_{t}, 1,2, \ldots N$ will be discussed below.

$$
S_{1 p h}\left(k_{t}\right)=\frac{s}{1+n} S_{1 p f}-\frac{n+d}{1+n} k_{t}, 0 \leq k_{t}<37 .
$$

Here $d=0,2$-depreciation rate, $s=0,3$-investment share, $n=0,004$ is a coefficient of the growth of person employed in economy:

$$
L_{t+1}(t)=(1+n) L_{t}, L_{t+N}(t)=L_{0}(1+n)^{N}, L_{0}=33 .
$$


It is easy to see that the phase curve $S_{1 p h}\left(k_{t}\right)$ (4) is a right-hand side of the modified Solow's equation

$$
k_{t+1}=S_{1 p h}\left(k_{t}\right) .
$$

In a similar way, we write down the equation for phase curve $S_{2 p h}\left(k_{t}\right)$

$$
S_{2 p h}\left(k_{t}\right)=\frac{s}{1+n} S_{2 p f}-\frac{n+d}{1+n} k_{t} \quad 37 \leq k_{t}<47
$$

and corresponding modified Solow's equation

$$
k_{t+1}=S_{2 p h}\left(k_{t}\right)
$$

and $S_{2 s s}\left(k_{t}\right)$ which are used to find steady states:

$$
S_{1 s s}\left(k_{t}\right)=s S_{1 f p}\left(k_{t}\right), S_{2 s s}\left(k_{t}\right)=s S_{2 f p}\left(k_{t}\right) .
$$

To find the steady state points of the variable $k_{t}$ of the modified Solow equation (9), we construct a diagram.

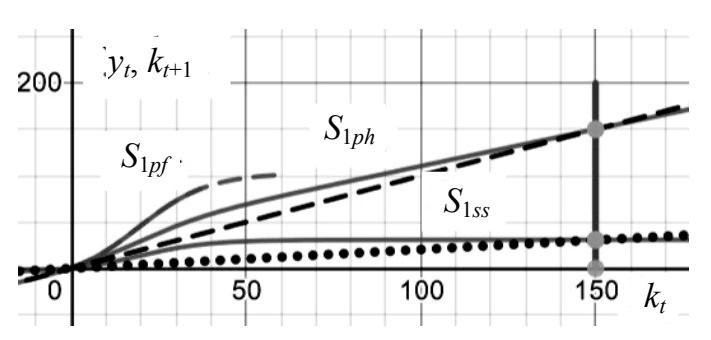

Fig. 4. Finding steady state points. Dotted line bisector $y=k_{t}$; dotted line - linear function $y=(n+d) k_{t}$

The Fig. 4 shows that steady state point of $y=k_{t}$ lies outside where equation (9) is considered and should not be taken into account. To control the correctness of the construction, you need to make sure that the steady state points generated by the phase curve $S_{1 p h}$ and $S_{1 s s}$ coincide.

Fig. 5 shows that steady state point of $y=k_{t}$ lies within where equation (10) is considered and should be taken into account. To control the correctness of the construction, you need to make sure that the steady state points generated by the phase curves $S_{2 p h}$ and $S_{2 s s}$ coincide.

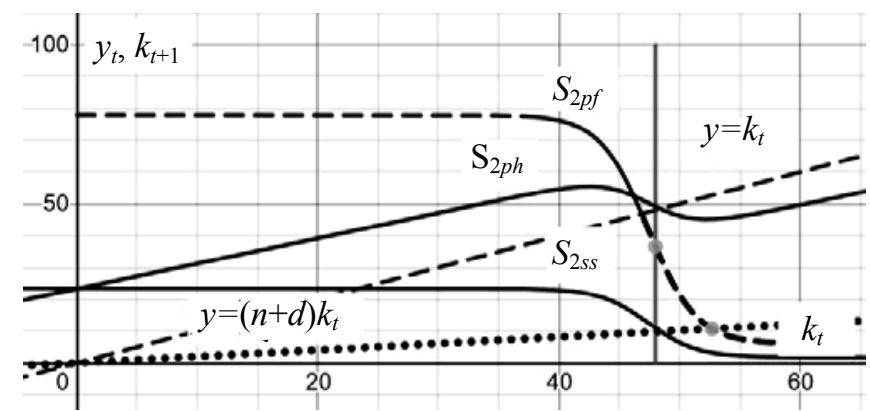

Fig. 5. Shows phase curves $S_{2 p h}$ and $S_{2 s s}$ coincide

\section{Dynamics of the modified Solow equation}

Let us introduce the 2-stage production function $S 2\left(k_{t}\right)$ given by equation

$$
S 2\left(k_{t}\right)= \begin{cases}S_{1 p f}\left(k_{t}\right), & \text { if } 0 \leq k_{t}<37, \\ S_{2 p f}\left(k_{t}\right), & \text { if } 37 \leq k_{t} \leq 47 .\end{cases}
$$


Output per worker $y\left(k_{t}\right)$ can be found from the relationship

$$
y\left(k_{t}\right)=S 2\left(k_{t}\right) .
$$

Let us introduce the 2-stage phase curve $S 2\left(k_{t}\right)$ given by equation

$$
G 2\left(k_{t}\right)= \begin{cases}S_{1 p h}\left(k_{t}\right), & \text { if } 0 \leq k_{t}<37 \\ S_{2 p h}\left(k_{t}\right), & \text { if } 37 \leq k_{t} \leq 47\end{cases}
$$

For the function $G 2\left(k_{t}\right)$, we can write down the modified Solow equation

$$
y\left(k_{t+1}\right)=G 2\left(k_{t+1}\right)
$$

This is a nonlinear discrete first order equation with piecewise continuous coefficients. The theory of first-order nonlinear discrete dynamical systems is well developed [10]. Numerical simulation is crucial in the investigation of nonlinear systems.Let us solve equation (11) and carry out a qualitative study of the equation. For this we use the E\&F Chaos software package [11] (see Figs 6-12).

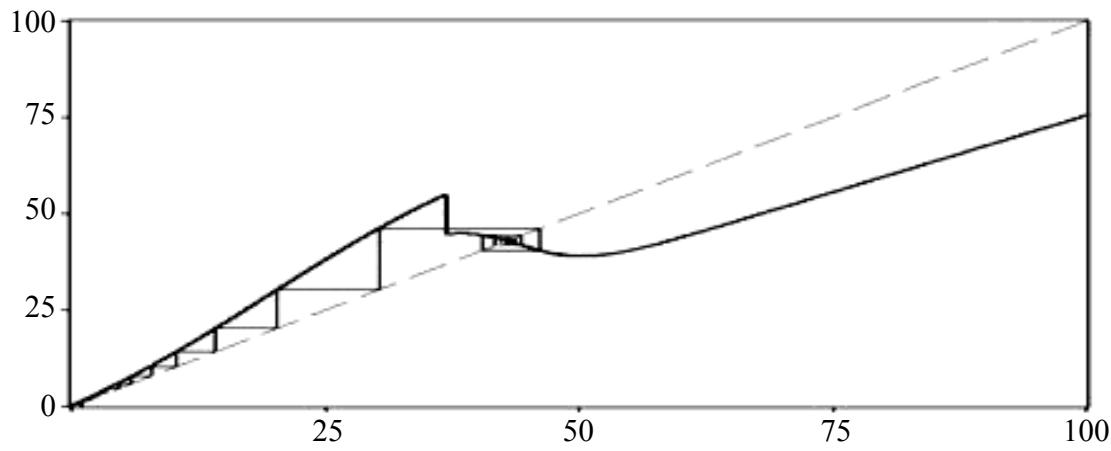

Fig. 6. The stable fixed point (stable 1-cycle) of equation of (11)

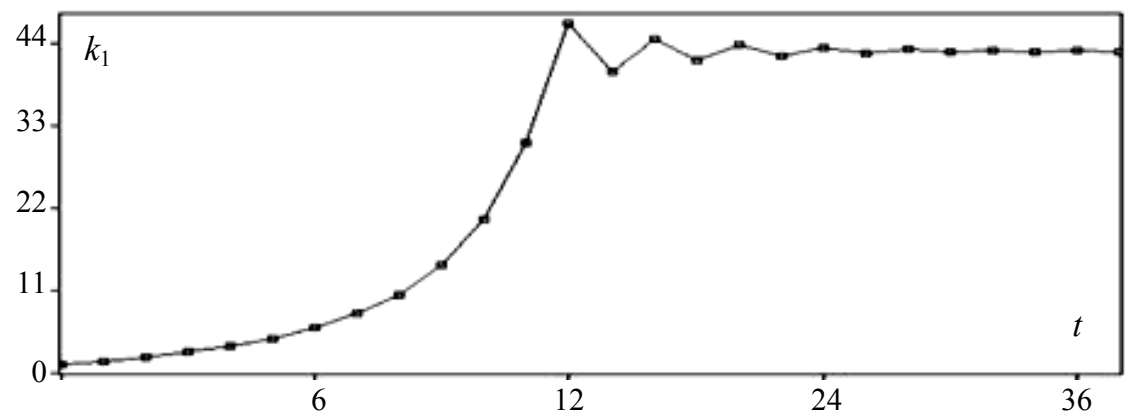

Fig. 7. The time series plots of stable 1-cycle of equation (11)

In fig. 8. As parameter $a_{5}$ increases from -1 to 0 , one observes: each stable cycle goes through an infinite sequence of period-doublings.

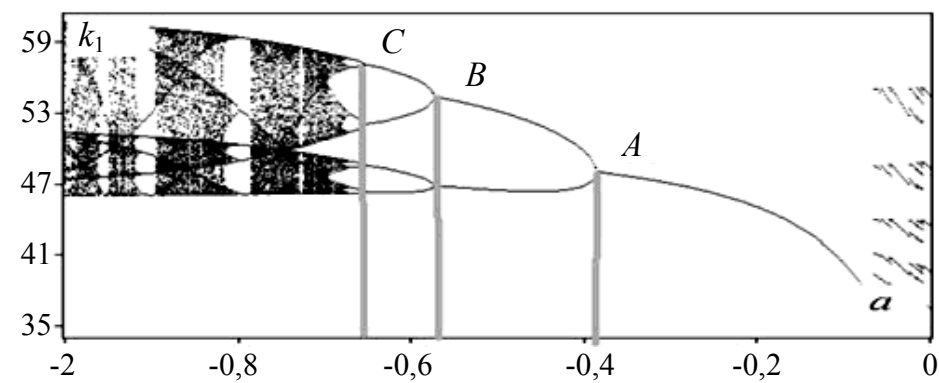

Fig. 8. Period doubling of flip bifurcation, with creation of a 2-cycle of (11) 
For example, the stable fixed point gives rise to a stable 2-cycle just as the fixed point becomes unstable.

This stable 2-cycle gives rise to a stable 4-cycle just as the 2-cycle becomes unstable. unstable.

This stable 4-cycle gives rise to a stable 8-cycle just as the 4-cycle becomes

In general, any stable $n$-cycle gives rise to a family

$$
2 n-\text { cycle } \rightarrow 4 n-\text { cycle } \rightarrow 8 n-\text { cycle } \rightarrow 16 n-\text { cycle. }
$$

The amplitude of $k n$-cycle goes to zero when $k$ goes infinity. Systems with two properties: bifurcation and period doubling, sensitive dependence to initial conditions or the largest Lyapunov exponent is positive are considered to be chaotic in a certain sense. These are termed as the routes to chaos.

In Fig. 9. The largest Lyapunov exponent is the average growth rate of an infinitesimal state perturbation along a typical trajectory (orbit). For periodic regimes the largest Lyapunov exponent is negative. This means that they are asymptotically stable by Lyapunov with respect to small changes in the initial conditions. For chaotic regimes the largest Lyapunov exponent is positive. This means that they are asymptotically unstable by Lyapunov with respect to small changes in the initial conditions (sensitive dependence to initial conditions).

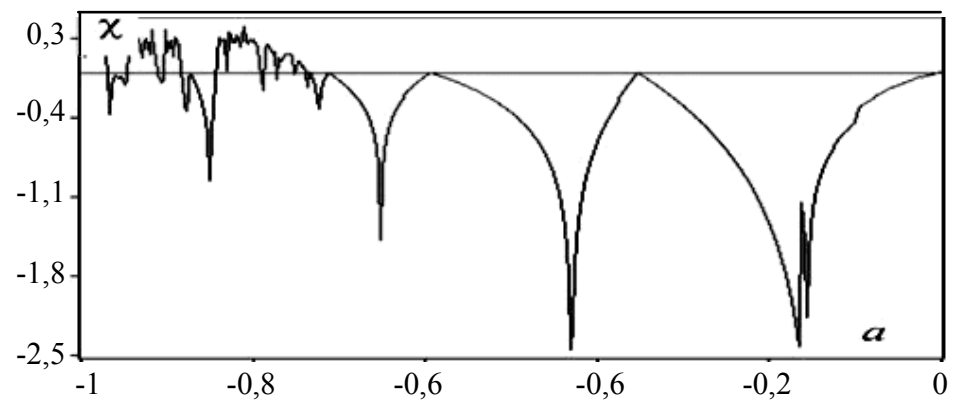

Fig. 9. The largest Lyapunov exponent $a_{5}$ increases from -1 to 0 for equation (11)

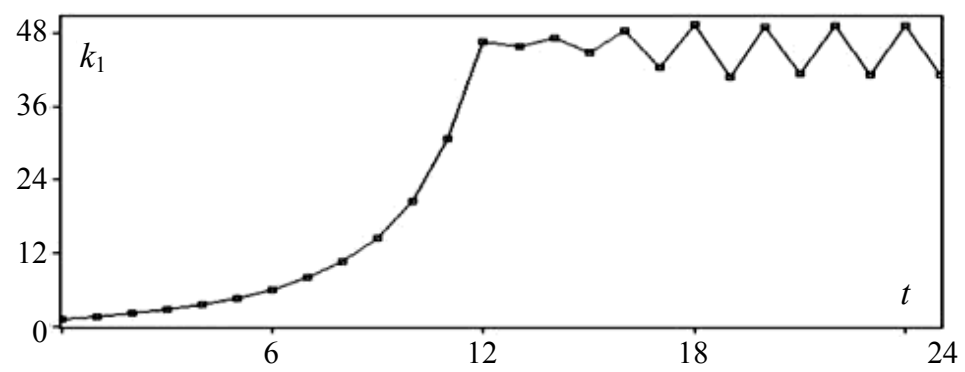

Fig. 10. Time series of stable 2-cycle at $a_{5}=-0,5$ of (11)

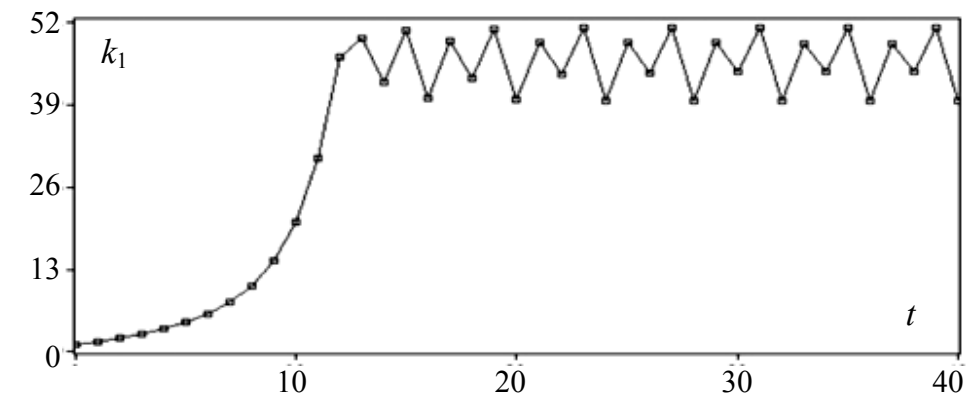

Fig. 11. Time series of stable 4-cycle at $a_{5}=-0,6$ of (11) 


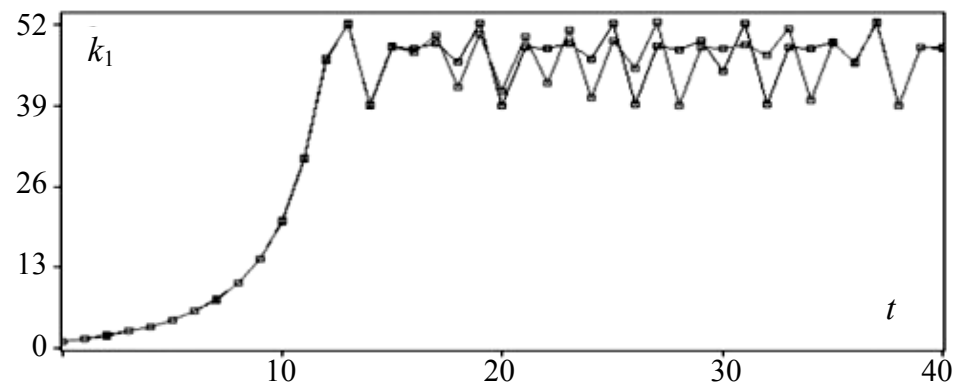

Fig. 12. Chaos:sensitive dependence on initial conditions at $a_{5}=-0,85$ of (11)

The diagram shows two trajectories under different initial conditions: blue $k_{0}=1,1$ and red $k_{0}=1,11$ despite the small difference in the values of the initial conditions, the trajectories first coincide and then diverge - the effect of the sensitivity of the solutions to the initial conditions.

\section{An example of a model based on real statistical data}

The intervals at which the drop in production occurs, for example, BC, DE, FG (Fig. 13), will be called the "technological gap" intervals. The very effect of this behavior is a "technological gap". This process is the result of a combination of economic, technological, socio-cultural, political and other events. The task of a healthy economy is to overcome this gap as quickly as possible and move to production growth.

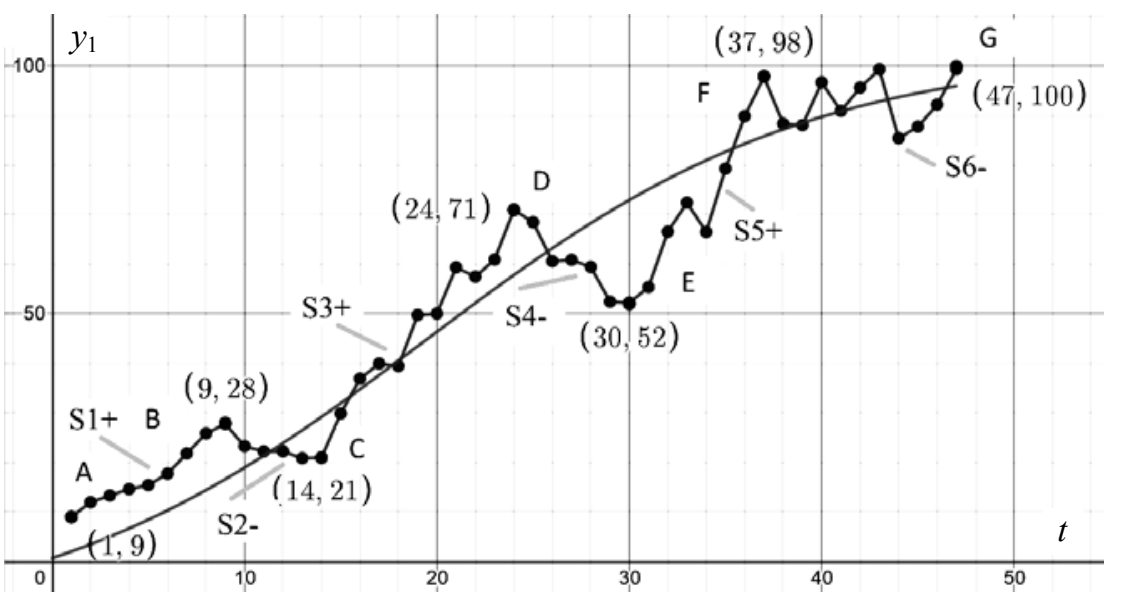

Fig. 13. GDP per person employed (current US \$) of Germany 1972-2018 by year numbers

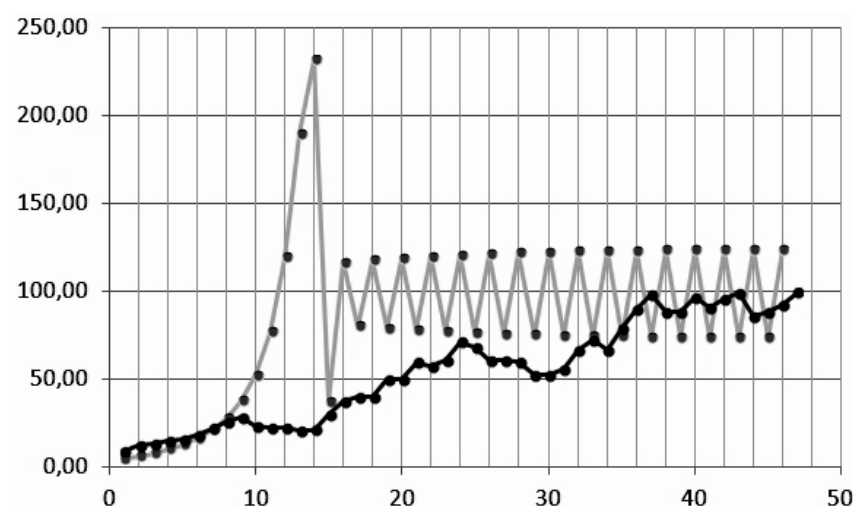

Fig. 14: Approximation of real data using the model in fig. 13 
The figures above explain the mechanism of behavior during the transition from a growing $S$-shaped production function to a decreasing $S$-shaped production function at a certain interval of functioning of the economic system under study.

\section{CONCLUSIONS}

Comparative analysis of the neoclassical Solow model and the modified Solow model in the implementation of technological progress has shown undeniable advantages of the modified Solow model. The exogenously introduced $S$-shaped production function describes the life cycle of technology at every: origin, leapfrogging, and gradual achievement of the stage of full maturity of a technological process or product at every stage. A modified version of the Solow economic growth model, based on an $n$-step production function in the form of $n$ $S$-shaped functions for the implementation of technological progress, ensures the growth of the economy by a sufficiently large time interval comparable to the duration of the life cycle of the economy under study.

The use of the theory of nonlinear dynamical systems to study solutions of the modified Solow model significantly improves their quantitative and qualitative characteristics. For the neoclassical model, this technique has not been used in full before.

A modified model, generating periodic and chaotic cycles for $2 S$-shaped production functions, is created. It explains the mechanism of behavior during the transition from a growing $S$-shaped production function to a decreasing $S$-shaped production function at a certain interval of functioning of the economic system under study. In this interval, referred to as the "technology gap", intensive output $y(t)$ can be carried out according to the following options (see Fig. 13, 14):

- Monotonic decrease (steady-state (stable 1-cycle) of the considered model.

- Oscillations (stable $n$-cycles, $n=1,2,4,16, \ldots$ ), "the economy marks time".

- Chaotic fluctuations. This result for the models of economic growth is fundamental and has not been described in the literature.

\section{REFERENCES}

1. Alexey Lopatin, "A Modified Version of Solow's Economic Growth Model with Successive Using Composite S-Curves for Technological Progress Implementation", 2020 IEEE 2nd International Conference on System Analysis Intelligent Computing (SAIC), 5-9 Oct. 2020, Kyiv, Ukraine, pp. 60-63. doi: 10.1109/SAIC51296.2020.9239116

2. Dmitry Kucharavy and Roland De Guio, "Application of S-shaped curves", TRIZ Future Conference 2007, Procedia Engineering, 9, 2011, 559572.

3. V.K. Semenychev, A.A. Korobetskaya, and V.N. Kozhukhova, Proposals of econometric tools for modeling and forecasting evolutionary processes: a monograph [in Russian]. Samara: SAGMU, 2015, 384 p.

4. Yu.N. Startsev, S-shaped development models and technological gaps [in Russian]. Available: https://cyberleninka.ru/article/n/s-obraznye-modeli-razvitiya-itehnologicheskie-razryvy

5. R.M. Nizhegorodtsev, "Logistic modeling of economic dynamics [in rus.], part 1", Problemy upravleniya, no. 1, pp. 46-53, 2004.

6. R.M. Solow, "A contribution to the theory of economic growth", Quarterly Journal of Economics, vol. 70 (1), pp. 65-94, 1956.

7. O.A. Zamulin and K.I. Sonin, "Economic Growth: Nobel Prize 2018 and Lessons for Russia", Voprosy Ekonomiki, no. 1, pp. 11-36, 2019. 
8. Pierre-Richard Agénor and Peter J. Montiel, Development Macroeconomics. Fourth Edition Princeton University Press, 2015, 792 p.

9. Leobardo Plata Perez and Eduardo Caldern, "A modified version of Solow- Ramsey model using Richard's growth function", Economia internacional y desarrollo, vol. 6, no. 1, pp. 65-70, 2009.

10. A. Medio and M. Lines, Nonlinear dynamics, A primer. Cambridge University Press, Cambridge, 2001.

11. Cees Diks, Cars Hommes, Valentyn Panchenko, and Roy van der Weide, "E\&F Chaos: A User Friendly Software Package for Nonlinear Economic Dynamics", Comput Econ., 32, pp. 221-244, 2008. doi: 10.1007/s10614-008-9130-x.

Received 30.06.2021

\title{
INFORMATION ON THE ARTICLE
}

Alexey K. Lopatin, ORCID: 0000-0002-0832-3600, Educational and Scientific Complex "Institute for Applied System Analysis" of the National Technical University of Ukraine "Igor Sikorsky Kyiv Polytechnic Institute", Ukraine, e-mail: lopatinalexey142@gmail.com

РЕАЛІЗАЦІЯ ТЕХНОЛОГІЧНОГО ПРОГРЕСУ НА ОСНОВІ МОДИФІКОВАНОЇ ВЕРСІЇ МОДЕЛІ ЕКОНОМІЧНОГО ЗРОСТАННЯ Р.М. СОЛОУ: $S$-ПОДІБНА КРИВА ВИРОБНИЦТВА, ЩО СКЛАДАЕТЬСЯ 3 n-КРОКІВ О.К. Лопатін

Анотація. Порівняльний аналіз неокласичної моделі Р. Солоу і її модифікованої версії в реалізації технологічного прогресу показав незаперечні переваги модифікованої моделі Солоу. Модифікована версія моделі економічного зростання Р. Солоу, що заснована на $n$-ступінчастій виробничій функції у вигляді $n$ $S$-подібних функцій для реалізації технічного прогресу, забезпечує зростання економіки на достатньо великому часовому інтервалі, порівнянному 3 тривалістью життєвого циклу досліджуваної економіки. В інтервалі, званому «технологічним розривом», інтенсивний випуск $y(t)$ може здійснюватися у відповідності 3 наступними варіантами: монотонне зниження продуктивності (стабільний 1-цикл) розглянутої моделі; коливання (стійкі $n$-цикли , $n=2,4,16$, ...), «економіка тупцює на місці»; хаотичні коливання. Перераховані результати для моделей економічного зростання в літературі не описані.

Ключові слова: модифікована модель Р. Солоу, технологічний розрив, періодичні цикли і хаос.

\section{РЕАЛИЗАЦИЯ ТЕХНОЛОГИЧЕСКОГО ПРОГРЕССА НА ОСНОВЕ МОДИФИЦИРОВАННОЙ ВЕРСИИ МОДЕЛИ ЭКОНОМИЧЕСКОГО РОСТА Р.М. СОЛОУ: S-ОБРАЗНАЯ КРИВАЯ ПРОИЗВОДСТВА, СОСТОЯЩАЯ ИЗ n-ШАГОВ / А.К. Лопатин}

\begin{abstract}
Аннотация. Сравнительный анализ неоклассической модели Р. Солоу и ее модифицированной версии в реализации технологического прогресса показал неоспоримые преимущества модифицированной модели Солоу. Модифицированная версия модели экономического роста Р. Солоу, основанная на $n$-ступенчатой производственной функции в виде $n S$-образных функций для реализации технического прогресса, обеспечивает рост экономики на достаточно большом временном интервале, сопоставимом с продолжительность жизненного цикла исследуемой экономики. В интервале, называемом «технологическим разрывом», интенсивный выпуск $y(t)$ может осуществляться в соответствии со следующими вариантами: монотонное снижение производительности (стабильный 1-цикл) рассматриваемой модели; колебания (устойчивые $n$-циклы, $n=2,4,16, \ldots)$, «экономика топчется на месте»; хаотические колебания. Перечисленные результаты для моделей экономического роста в литературе не описаны.
\end{abstract}

Ключевые слова: модифицированная модель Р. Солоу, технологический разрыв, периодические циклы и хаос. 